International Migration and Human Rights 
This page intentionally left blank 


\section{International Migration and Human Rights}

The Global Repercussions of U.S. Policy

EDITED BY SAMUEL MARTÍNEZ

\section{ए G)}

Global, Area, and International Archive University of California Press 
The Global, Area, and International Archive (GAIA) is an initiative of International and Area Studies, University of California, Berkeley, in partnership with the University of California Press, the California Digital Library, and international research programs across the UC system. GAIA volumes, which are published in both print and openaccess digital editions, represent the best traditions of regional studies, reconfigured through fresh global, transnational, and thematic perspectives.

University of California Press, one of the most distinguished university presses in the United States, enriches lives around the world by advancing scholarship in the humanities, social sciences, and natural sciences. Its activities are supported by the UC Press Foundation and by philanthropic contributions from individuals and institutions. For more information, visit www.ucpress.edu.

University of California Press

Berkeley and Los Angeles, California

University of California Press, Ltd.

London, England

(C) 2009 by The Regents of the University of California

Library of Congress Cataloging-in-Publication Data

International migration and human rights : the global repercussions of U.S. policy / edited by Samuel Martínez.

p. $\quad \mathrm{cm}$. (Global, area, and international archive)

Includes bibliographical references and index.

ISBN: 978-0-520-25821-1 (pbk. : alk. paper)

1. Emigration and immigration-Government policy.

2. Immigrants-Civil rights. 3. United States-Emigration and immigration-Government policy. 4. ImmigrantsCivil rights-United States. 5. United States-Foreign relations1989- . I. Martínez, Samuel, 1959- .

JV6038.1616 2009

325.73 - dc22

2009023255

(C) Manufactured in the United States of America

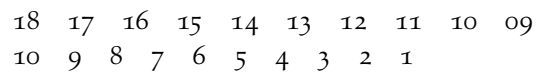

The paper used in this publication meets the minimum requirements of ANSI/NISO z39.48-1992 (R 1997) (Permanence of Paper). 
In memory of Richard Rust, Nelson Enríquez,

Daniel Zarrow, Joseph Danticat, and the uncounted thousands more who have fallen victim to immigration restrictionism 
This page intentionally left blank 